\title{
Collaborative Partnerships to Support Faculty Development in the Information Age
}

\author{
Kimberlye P. Joyce \\ Instructional Designer \\ Academic Technology Services \\ University of Richmond \\ 804.287.6872, USA \\ kjoyce@richmond.edu
}

\author{
Marvette Johnson \\ Technology Learning Center \\ Specialist \\ Academic Technology Services \\ University of Richmond \\ 804.289.8777, USA \\ mjohnso5@richmond.edu
}

\author{
Lucretia McCulley \\ Head, Outreach and Instruction \\ Services \\ Boatwright Memorial Library \\ University of Richmond \\ 804.289.8670, USA \\ Imcculle@richmond.edu
}

\author{
John Outland \\ PETE Coordinator \\ Professor of Political Science \\ University of Richmond \\ 804.289.8534, USA \\ joutland@richmond.edu
}

\author{
Fran White \\ Coordinator of ATS \\ Academic Technology Services \\ University of Richmond \\ 804.287.6866, USA \\ fwhite@richmond.edu
}

\begin{abstract}
The purpose of this paper is to describe and reflect upon the successful results of an innovative collaborative partnership among faculty and professional support staff at the University of Richmond.
\end{abstract}

\section{Keywords}

Faculty, support development, collaboration, partnerships.

\section{INTRODUCTION}

The University of Richmond Information Services organization has developed an innovative model to meet the demands for faculty support and development. This model has evolved over time, as rapidly changing information age technologies have reshaped traditional faculty support structures. As a result, the perceptions of the various participants in this partnership have been positive and reinforcing, and there has been a significant improvement in the effectiveness of our workshops, events, and collaborative efforts to support teaching, learning, and technology.

This has been accomplished through a triangular partnership of complementary expertise at the University of Richmond,

\section{LEAVE THIS TEXT BOX IN PLACE}

AND BLANK including support from three key elements in this partnership:

- Faculty: Program for Enhancing Teaching Effectiveness (PETE)

- Librarians: Outreach and Instruction Services (OIS)

- Technology Professionals: Academic Technology Services (ATS)

\section{COLLABORATIVE PARTNERS}

Information Services encompasses both the Library and Technology infrastructures at the University of Richmond. Departments directly providing faculty support include Outreach and Instruction Services (OIS) Librarians and Academic Technology Services (ATS) Professionals. Through ongoing conversations with faculty on the PETE committee and members of OIS and ATS, a collaborative partnership has been formed to further enhance teaching by providing faculty development opportunities designed to address the added pressures that the Information Age has imposed upon teaching and learning.

The Program for Enhancing Teaching Effectiveness (PETE) has been in existence since 1976 and is designed to help sustain the vitality of teaching at the University of Richmond. The program is administered by a committee of ten faculty members and a faculty coordinator. The committee members represent a variety of approaches to teaching; their charge is not to advocate particular theories or practices, but rather to encourage discussion and reflection about teaching and to foster the efforts of faculty to be the most effective teachers they can be 
Outreach and Instruction Services (OIS) consists of 10 professional librarians who provide liaison services to various academic departments. These librarians work closely with faculty in their departments regarding collection purchases for the libraries; provide in-depth reference service; teach information literacy classes to students, staff and faculty; and meet any other library/information need that faculty may require. Librarians also work closely with the students in liaison departments as they move into their major courses. In addition, OIS librarians provide extensive "walk-in" reference assistance to library users of all types in their respective library locations.

Academic Technology Services (ATS) consists of 11 technology professionals who also provide liaison services to academic departments. 1 These staff professionals collaborate with faculty to assist with the integration of technology into teaching and research. In addition, they provide a variety of programs and resources and serve on collaborative project teams that support teaching and learning. Some of these resources include: learning opportunities to improve technology skills for faculty, staff, and students; electronic tools, course management systems and resources that can expand the classroom; management and support for computer labs; facilities and equipment that support the academic curriculum; a Technology Learning Center (TLC) that $_{\text {the }}$ supports technology and multimedia development by faculty and provides self-study training resources; and direct support for the new Center for Teaching, Learning and Technology In all cases, support may be provided directly by a liaison, by referral to another member of the IS staff or by outsourced professionals.

Each of these groups offers knowledge and abilities; however, none of these groups by itself is likely to promote faculty development effectively, no matter how sincere and earnest the efforts. We soon realized that if these groups came together and formed a collaborative partnership, we could develop a set of effective workshops, events and support structures that would promote faculty development. Examples of our collaborative successes include co-sponsoring an Information Literacy Think Tank with follow-up Information Fluency workshops, an annual Techology Fair, better collaboration on technology related grant processes, occasional brown bag luncheon discussions and demonstrations, and the creation of an Award for Excellence in Teaching, Learning and Technology.

\section{COLLABORATIVE SUCCESSES}

We have had a number of successful events over the past couple of years as a direct result of our collaborative partnership.

\subsection{Information Literacy Think Tank}

Thanks to a grant from PETE, an Information Literacy Think Tank was sponsored by OIS and ATS on May 24-25, 1999. Faculty members came together with personnel from OIS and ATS to explore the ways in which information literacy skills can be integrated into teaching and the curriculum.

"Information literacy is a survival skill in the information age. Instead of drowning in the abundance of information that floods their lives, information-literate people know how to find, evaluate, and use information effectively to solve a particular problem or make a decision." (Patricia S. Breivik and E. Gordon Gee, Information Literacy (New York: Macmillan, 1989), p. 12-13)

On the first day of the workshop, James Neal, dean of university libraries at the Johns Hopkins University and a recent president of the Association of Research Libraries, led the group through discussion and exercises that allowed them to understand the issue's complexity. On the second day, faculty brainstormed about ways in which the University of Richmond can provide students with learning experiences that will equip them with information literacy skills for application in both their academic work and their careers after graduation. Through the ideas and plans that emerged from the two-day Think Tank, the University of Richmong is poised to provide national leadership on this problem.

\subsection{Action Steps and Plan}

As a result of the Think Tank, we produced a list of needs, key ideas, immediate action steps and a longer-range action plan. Participants identified actions that would begin to teach students information literacy concepts and skills. Some of these action steps included:

- The use by faculty of the services of library and ATS liaisons in at least one course per semester.

- The design by faculty of courses which incorporate online discussion groups, group assignments, and ongoing collaborative roles for librarians and ATS staff; these courses should nurture the creation of learning communities.

- The expansion of the libraries' and ATS liaison programs to enable greater/more frequent interaction and consultation with faculty.

During the 1999-00 academic year, a number of OIS and ATS staff worked with faculty to implement the ideas and action steps proposed during the think tank. The outcomes of this work were shared with attendees at our annual Technology Fair.

\subsection{Tech Fair 2000}

"Tech Fair 2000: Bringing Teaching, Learning and Technology Together" was held May 3-4, 2000 at the University of Richmond. The goal of the event was to provide an opportunity for our faculty to share experiences with the latest technologies and integration of best practices for teaching and learning. An annual event, Tech Fair is a small and informal conference for University of Richmond faculty, technology and library staff. This event began as an extension of our hands-on training for technology and was also an outgrowth of annual PETE teaching workshops which had been held each May for the last ten years. Over the past four years, ATS and OIS have co-sponsored this event with PETE, and it has evolved into a much richer opportunity for faculty development than ever imagined. 
This year, Tech Fair 2000 was designed to demonstrate possibilities to improve teaching and learning through the effective use of information and technology resources. We experienced a $25 \%$ increase in attendance and a rich program designed around the following session topics:

- $\quad$ Faculty Best Practices

- Pedagogy and Technology: Successes and Frustrations

- Curriculum and Instructional Strategies

- Web-based Teaching and Learning

- Information Fluency

- $\quad$ Current and Emerging Technologies

\subsection{Information Fluency Task Force}

As a follow-up to last Spring's Think Tank initiative and our involvement with the Associated Colleges of the South initiative on Information Fluency (IF), an IF taskforce was formed consisting of OIS and ATS teams. This group meets on a monthly basis and shares information critical to the integration of Information Fluency into the curriculum at Richmond. In Spring 2000, the taskforce offered two Information Fluency workshops. These workshops brought together faculty and liaisons from a variety of disciplines and gave them the chance to discuss information literacy issues and to design effective class assignment modules that would include information literacy concepts and/or information technology. Faculty were excited by the opportunity to work closely with both the ATS and OIS liaisons and to have full-day workshops devoted to planning new assignments and syllabi for the coming academic year. Collaborations begun in that workshop will be continuing throughout the summer.

\subsection{PETE Grants}

In addition to co-sponsoring faculty development events and workshop opportunities with OIS and ATS, PETE has funds at its disposal to support activities that invigorate teaching. During the 1998-99 academic year, PETE awarded 24 travel, workshop and materials grants ranging from $\$ 160$ to $\$ 1500$, as well as one exceptional materials grant of $\$ 3350$. In addition, PETE provided 21 individual summer grants ranging from $\$ 1200$ to $\$ 3000$. The focus for the majority of summer grants was on the integration of technology into the classroom. While the funds available for 1999-2000 were somewhat less, PETE was nonetheless able to fund many pedagogically related projects involving the use of technology.

Information Services (IS) staff, including OIS and ATS as well as many other IS departments have played key roles in partnering with faculty as they planned, wrote and put into action those proposals associated with grants involving technology. The PETE committee encouraged applications for projects that would integrate scholarship or pedagogy from a broad variety of areas, including the integration into courses of pedagogy based on new technologies. Priority in awarding grants went to projects that were innovative and would have a broad impact on the curriculum of a department or program.

\subsection{Faculty Technology Award}

Academic Technology Services was also given the task of finding a new way to encourage faculty to enhance their teaching with the use of technology. In the past, we have offered workshops, Tech Fair, classes and one-on-one sessions with faculty. While having been quite successful with these efforts, we continued to struggle with a sense that faculty perceived a lack of recognition for their efforts. The Award for Excellence in Teaching, Learning and Technology was conceived during a conversation about such recognition. It is our hope that the award will have the same significance in our community as the University's Distinguished Educator Award. To ensure this, we sent our proposal to President Cooper and the Academic Deans and received enthusiastic support. Seven faculty members were honored in March, 2000 at our first award ceremony, receiving a total of $\$ 10,000$ in award monies. We anticipate presenting this award on an annual basis.

The award honors those, working individually or in teams, who demonstrate excellence in teaching by extending the classroom with integration of instructional technology into course delivery. The primary criterion for the award is innovation and leadership in the integration of teaching, learning and technology. An individual may be nominated for the award by his or her department chair or dean or by members of the Academic Technology Services team. There are three categories of awards:

- An established, tenured or continuing faculty member (four or more years of service)

- A tenure-track faculty member who has been with the University for three years or less

- A faculty member who serves in a non-continuing capacity.

The selection committee consisted of all members of the Academic Technology Services team. Candidates' evidence of integration of technology into teaching and learning was reviewed using the following guidelines:

- Demonstrated use of technology that supports accepted practices and principles of pedagogy.

- Demonstrated commitment to using technologies in teaching beyond a single project.

- Demonstrated effective use and dissemination of technology that is applicable to a broad spectrum of the University curriculum.

- Demonstrated a positive change in the way students are taught by expanding the classroom.

- Demonstrated commitment to assisting peers in the effective use of technology.

- Demonstrated commitment to articulate and share with peers successful implementation of technology from concept to production.

- Demonstrated effort to share the final technology application with other faculty.

\section{RESULTS AND FUTURE DIRECTIONS}

Results of this partnership have been very positive for all involved. Gray areas of support have been eliminated and we feel we are now better addressing faculty needs and learning styles. 
With more on-demand services and support, time constraints of faculty are being attended to. Better defined roles of both OIS and ATS staff have helped to shape and meet faculty expectations. More mainstream faculty are now engaged in efforts to integrate technology and information resources into their teaching and research. Communication between OIS, ATS and PETE has greatly improved opportunities for developing effective models for change. As a result, faculty empowerment to use technology effectively has increased, and the enthusiasm that has been generated has been a motivating and rewarding experience for all involved.

The future of OIS, ATS, and faculty partnering appears to be especially promising as a result of two additional initiatives undertaken during the 1999-2000 academic year. The first involves the creation of a new Center for Teaching, Learning, and Technology which will consolidate and help to institutionalize many of the academic and technological support services described in this paper. This center will be headed by a Director of Teaching, Learning, and Technology who will have dual reporting lines to both the Vice President for Information Services and the academic Deans of the University. The new director will become Coordinator of the PETE Committee which, in turn, will serve as the director's faculty advisory body. In addition, the director is expected to establish collaborative relationships with other core support areas, such as the Library, the Media Resource
Center, the Writing Center, the Speech Center, and our experiential learning programs. This position was filled, as of July 1, 2000 by Patricia A. Schoknecht, Ph.D., formerly of Rutgers, The State University of New Jersey.

The second major development, a consequence of the University's new Strategic Plan adopted during the Spring of 2000, represents an even greater evolutionary step in the direction of collaborative partnering. As one of five major "program innovations," the University has undertaken a broad based commitment to the promotion among its students of technology and information fluency skills. This commitment will require an increase in the professional staff of academic technologists and librarians/information specialists who will work with faculty and students to ensure that appropriate technology and information fluency will be further integrated into the University's teaching and learning environments. The end objective, of course, is to see that University of Richmond students will be equipped with the knowledge and critical thinking skills that will allow them to function effectively in the new information age. Thus, the original collaborative partnership among PETE, OIS, and ATS has now blossomed into a university-wide undertaking to meet the $21 \mathrm{st}$ century technology/information fluency needs of both faculty and students. Needless to say, this is an exciting development for those of us who have been involved in the maturation of this idea.

\section{Endnote References}

\footnotetext{
${ }^{1}$ PETE Committee Members for 1999-2000 include:
}

- $\quad$ Ronald Bacigal, Law

- David Dean, Economics

- Dafna Eylon, Management

- Terryl Givens, English

- Brad Goodner, Biology

- $\quad$ Elisabeth Gruner, English

- John Outland, PETE Coordinator, Political Science

- Jeff Riehl, Music

- Joanne Ciulla, Leadership Studies

- $\quad$ Ellen Walk, Continuing Studies

- Della Fenster, Math and Computer Science

\footnotetext{
${ }^{2}$ OIS includes the following library staff members:
}

- $\quad$ Lucretia McCulley, Boatwright Library, (Women's Studies \& Leadership Studies)

- McKinley Sielaff, Boatwright Library, (Political Science, Military Science \& Government Information)

- $\quad$ Lee Stevens, Boatwright Library, (Art, Education, International Education, Russian Language and Literature, Spanish Language and Literature, Speech Communication, Theatre and Dance)

- Jim Gwin, Boatwright Library, (History)

- Marcia Whitehead, Boatwright Library, (Classical Studies, English Language and Literature, French, German, Philosophy, Religion)

- $\quad$ Nancy Woodall, Boatwright Library, (Psychology, Sociology and Anthropology)

- Lit Maxwell, Business Information Center, (Accounting, Business Administration, Economics, Finance, Management, Marketing) 
- $\quad$ Paul Porterfield, Media Resource Center, Journalism, School of Continuing Studies, Media Resources (video, audio, satellite programming, video production)

- $\quad$ Bonny Hall, Music Library,(Music)

- $\quad$ Melanie Hillner, Science Library(Biology, Chemistry, Physics, Health and Sport Science, Mathematics and Computer Science)

${ }^{3}$ ATS includes the following staff members:

- $\quad$ Leanne Battle, Academic Technology Consultant (Classical Studies, Sociology and Anthropology, Music, Art, Philosophy, Religion, Theatre and Dance, Women's Studies)

- $\quad$ Kathy Bruckner, Boatwright Computer Classroom Specialist

- $\quad$ Laura Byrd, Academic Technology Consultant (School of Continuing Studies, Health and Sport Science, English, Chemistry, Education, Math and Computer Science, Military Science)

- Cely Coleman, Academic Technology Consultant (Political Science, American Studies, Physics, English, Leadership Studies, History, Journalism)

- $\quad$ Melissa Foster, Information \& Technology Specialist (Psychology and Modern Languages and Literatures)

- Marvette Johnson, Technology Learning Center Specialist

- Kimberlye Joyce, Instructional Designer (Accounting, Economics, Finance, Management Systems, Marketing, Rhetoric and Communications, Biology)

- $\quad$ Rene Kanters, Director of Computer Assisted Education in the Sciences

- $\quad$ Laurel Moore, Computer Lab Manager

- $\quad$ Rick Neal, Computer Lab Specialist

- $\quad$ Andrew Ross, Director of Multimedia Language Lab

- $\quad$ Fran White, Coordinator of Academic Technology Services

${ }^{4}$ For more information on the Technology Learning Center see: http://www.richmond.edu/is/tlc

${ }^{5}$ For more information on the Center for Teaching, Learning and Technology see: http://www.richmond.edu/is/ats/tltcenter.html

${ }^{6}$ Information about the Think Tank event and a follow-up report can be found at: http://www.richmond.edu/is/faculty/thinktank99/.

${ }^{7}$ For information on Tech Fair 2000 see: http://www.richmond.edu/is/faculty/techfair2000/.

${ }^{8}$ Guidelines for these grants can be found at: http://www.richmond.edu/pete/grants.html. 